\title{
Is the Wild Coast in eastern South Africa a distinct marine bioregion?
}

\author{
Candice M. Jooste, Jody Oliver, Arsalan Emami-Khoyi and Peter R. Teske* (i)
}

\begin{abstract}
The South African coastline can be divided into at least four temperature-defined marine bioregions, including the tropical north-east coast, the subtropical east coast, the warm-temperate south coast, and the cool-temperate west coast. There are also two biogeographical transition zones, the south-west coast and the south-east coast (or Wild Coast). The former is sometimes considered a distinct marine bioregion, but no such status has yet been suggested for the Wild Coast. Previous data on the distribution of a recently described but very common coastal crab, Hymenosoma longicrure, indicated that this species could be a Wild Coast endemic. If confirmed, this would be a first indication that this region harbours unique fauna, and that additional research is required to determine whether the Wild Coast constitutes a distinct bioregion that needs to be managed separately from other coastal regions. In the present study, we generated novel genetic data for $\mathrm{H}$. longicrure and compared the species' range with that of its southern African congeners. We found that $\mathrm{H}$. longicrure occurs north of the Wild Coast, where its range overlaps with that of $\mathrm{H}$. projectum. This finding rejects the idea that the Wild Coast harbours endemic fauna and suggests that the ranges of the two species may be linked to the subtropical and tropical bioregions, respectively, with some southward dispersal facilitated by the southward-flowing Agulhas Current. We conclude that there is as yet no compelling evidence that the Wild Coast is a distinct marine bioregion, and concur with previous biogeographical studies which have suggested that the Wild Coast is an area in which species from the subtropical and warm-temperate bioregions have overlapping ranges. Nonetheless, that fact that no biological information is available for the majority of the region's estuaries highlights the necessity of comprehensively documenting the biodiversity of this understudied region to fully resolve this issue.
\end{abstract}

Keywords: Biogeography, Crab, Endemic species, Marine biodiversity, South Africa, Transition zone, Wild Coast

\section{Background}

The coastline of South Africa is exceptionally diverse. Located at the contact area of the Atlantic and Indian Ocean biomes, it not only comprises biotic elements from two oceans [1], but there are also large numbers of endemics [2-4]. Environmental conditions change considerably from west to east and based on species assemblage data, most authors have accepted three major temperature-defined coastal marine biogeographical regions, including the cool-temperate Namaqua bioregion in the west, the warm-temperate Agulhas bioregion

${ }^{*}$ Correspondence: pteske101@gmail.com

Department of Zoology, Centre for Ecological Genomics and Wildlife

Conservation, University of Johannesburg, Auckland Park 2006, South Africa in the south, and the subtropical Natal bioregion in the east [2, 5-7] (Fig. 1). Genetic data indicate that the boundaries between these marine bioregions are mirrored below the species level, as numerous cryptic sister species that are morphologically difficult to distinguish have been found in adjacent bioregions [8].

Several recent studies have suggested that there is also a tropical region in the north-east (the Delagoa bioregion [3, 9]; Fig. 1), and genetic data strongly support this $[8,10-13]$. There are also two major biogeographical transition areas whose status as bioregions is less clear. The region between the two temperate bioregions in the south-west has been treated as a transition zone in the older literature [14-16], but more recently it has been referred to as the South-western Cape bioregion [3]. Although the distinctness of the region from 


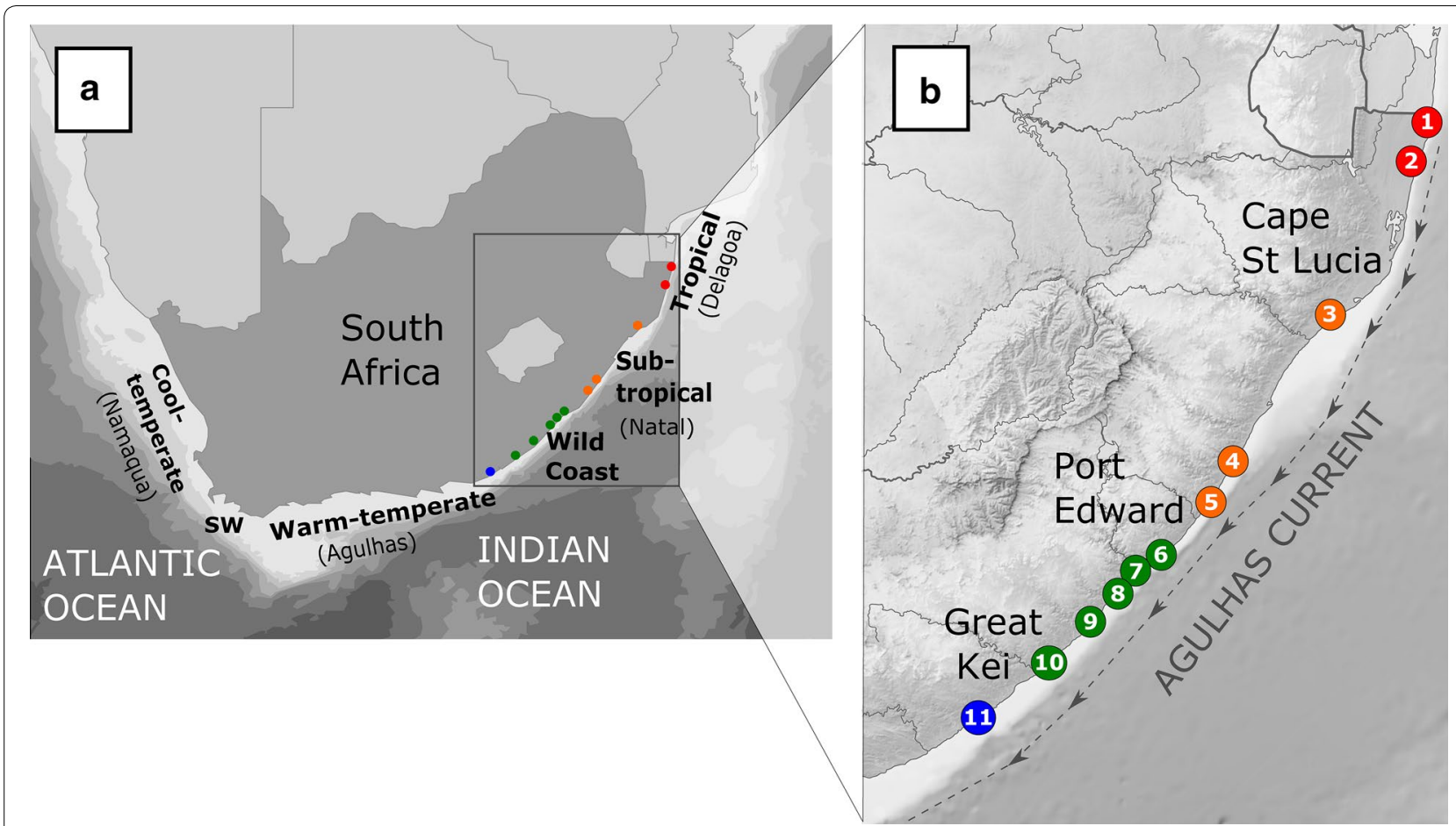

Fig. 1 Maps illustrating South African marine bioregions (a) and sampling sites for three species of Hymenosoma along the south-east coast of South Africa (b). Site numbers (1-11) correspond to those in Table 1

the temperate bioregions has been confirmed by some genetic studies based on endemic cryptic species [1721 , there is considerable disagreement about its exact location $[3,8,20]$.

The status of the other transition zone (located between the warm-temperate and subtropical bioregions) as a distinct bioregion is less strongly supported. This region, which is known as the Wild Coast and is roughly located between the Great Kei River and Port Edward (Fig. 1), has been described as an area rich in species endemic to South Africa [2] and there are distinct faunal discontinuities that include a rapid increase in the proportion of warm-water rocky shore species north of Port St Johns [21] and a distinct change in sandy beach macrofauna [22]. Based on community data, some authors have grouped the Wild Coast with the warm-temperate south coast [2] while others have grouped it with the subtropical east coast $[6,23]$, or found conflicting affinities depending on the methods used [9].

While some studies using species assemblage data found that Wild Coast sites formed distinct but weakly differentiated clusters $[2,5]$, the strongest support for the distinctness of this region comes from genetic data: the limpets Scutellastra barbara and S. longicosta [24] both have unique south-eastern lineages in this region, and there is also a south-eastern lineage of the shrimp
Palaemon capensis [25], although its range is slightly south of that described above. So far, there is only one example of a taxonomically described species that may be endemic to the Wild Coast: the coastal crown crab Hymenosoma longicrure [26]. This species was previously referred to as $H$. orbiculare [27], but it was identified as a distinct cryptic species based on genetic data, together with one more coastal crown crab ( $H$. projectum [26]) and two deeper-water species (H. trilobatum [26] and $H$. geometricum [28]) that were also formerly lumped with H. orbiculare [13, 29, 30]. Subsequent morphological analyses confirmed their species status [26]. The South African distribution records of $H$. orbiculare, $H$. longicrure and $H$. projectum indicate links with distinct coastal areas, with $H$. orbiculare being present throughout the temperate regions, $H$. longicrure along the Wild Coast, and $H$. projectum in the subtropical and tropical regions $[12,13,26,29,31-34]$.

The fact that many species in eastern South Africa often occur far outside their normal ranges because they are transported southwards by the Agulhas Current [33], and numerous species migrate northwards [34], may have made it difficult to clearly identify this region as distinct because resident species are outnumbered by migrants. The identification of endemics that are adapted to the intermediate temperatures of the Wild Coast would 
provide support for its status as a distinct bioregion, in the same way the south-west coast is now treated as such [3]. In the present study, the distribution of the three coastal species of Hymenosoma was re-assessed using data from additional sampling sites, with the specific aim of confirming that $H$. longicrure is indeed a Wild Coast endemic. Given the difficulties involved in distinguishing the three species in the field, genetic methods were used to verify their identity.

\section{Materials and methods}

\section{Genetic data generation}

Samples were collected from estuaries located on the Wild Coast and in the subtropical marine bioregion (Table 1) using a D-frame net. Each specimen had one leg removed and placed into an Eppendorf tube containing $10 \mu \mathrm{l}$ of Proteinase K and $180 \mu \mathrm{l}$ of CTAB Buffer [35], after which the specimen was released. The samples were taken back to the laboratory within a week of collection, and additional Proteinase $\mathrm{K}$ was added every 2 days to prevent the growth of microbes, for a total of $20 \mu \mathrm{l}$ of Proteinase K. DNA extraction was then completed in the laboratory using the CTAB method [35]. The data generated were supplemented with data from previous studies for a total of 11 study sites ranging from the tropical to the warm-temperate bioregions $[13,32]$.

Table 1 Sampling locality information with coordinates and specific marine bioregions in which samples were collected

\begin{tabular}{|c|c|c|c|c|}
\hline Site no. & Site name & Coordinates & Bioregion & No. sequences \\
\hline 1 & kuHlange & $\begin{array}{l}26^{\circ} 54^{\prime} 42^{\prime \prime} \mathrm{S}_{;} \\
32^{\circ} 52^{\prime} 00^{\prime \prime} \mathrm{E}\end{array}$ & Tropical & 7 \\
\hline 2 & Lake Sibaya & $\begin{array}{l}27^{\circ} 24^{\prime} 24^{\prime \prime} S_{i} \\
32^{\circ} 42^{\prime} 09^{\prime \prime} \mathrm{E}\end{array}$ & Tropical & 2 \\
\hline 3 & Mzingazi & $\begin{array}{l}28^{\circ} 47^{\prime} 44^{\prime \prime} S_{;} \\
32^{\circ} 04^{\prime} 15^{\prime \prime} \mathrm{E}\end{array}$ & Subtropical & 10 \\
\hline 4 & Mzimkhulu & $\begin{array}{l}30^{\circ} 44^{\prime} 59^{\prime \prime} \mathrm{S} \\
30^{\circ} 27^{\prime} 01^{\prime \prime} \mathrm{E}\end{array}$ & Subtropical & $35^{*}$ \\
\hline 5 & Mpenjati & $\begin{array}{l}30^{\circ} 58^{\prime} 19^{\prime \prime} \mathrm{S} \\
30^{\circ} 17^{\prime} 02^{\prime \prime} \mathrm{E}\end{array}$ & Subtropical & $2+6^{*}$ \\
\hline 6 & Mntafufu & $\begin{array}{l}31^{\circ} 33^{\prime} 49^{\prime \prime} \mathrm{S} \\
29^{\circ} 38^{\prime} 10^{\prime \prime} \mathrm{E}\end{array}$ & Wild Coast & $31^{*}$ \\
\hline 7 & Mzimvubu & $\begin{array}{l}31^{\circ} 37^{\prime} 18^{\prime \prime} \mathrm{S}_{i} \\
29^{\circ} 33^{\prime} 04^{\prime \prime} \mathrm{E}\end{array}$ & Wild Coast & 4 \\
\hline 8 & Mngazana & $\begin{array}{l}31^{\circ} 41^{\prime} 29^{\prime \prime} \mathrm{S} \\
29^{\circ} 25^{\prime} 24^{\prime \prime} \mathrm{E}\end{array}$ & Wild Coast & $54^{*}$ \\
\hline 9 & Mbhanyana & $\begin{array}{l}32^{\circ} 13^{\prime} 41^{\prime \prime} \mathrm{S} ; \\
28^{\circ} 55^{\prime} 43^{\prime \prime} \mathrm{E}\end{array}$ & Wild Coast & $57^{*}$ \\
\hline 10 & Qolora & $\begin{array}{l}32^{\circ} 37^{\prime} 49^{\prime \prime} \mathrm{S}_{;} \\
28^{\circ} 25^{\prime} 59^{\prime \prime} \mathrm{E}\end{array}$ & Wild Coast & 47 \\
\hline 11 & Gqunube & $\begin{array}{l}32^{\circ} 55^{\prime} 53^{\prime \prime} \mathrm{S} \\
28^{\circ} 01^{\prime} 45^{\prime \prime} \mathrm{E}\end{array}$ & $\begin{array}{l}\text { Warm-temper- } \\
\text { ate }\end{array}$ & 30 \\
\hline
\end{tabular}

The asterisks indicate novel sequences generated for this study
The cytochrome oxidase $c$ subunit I gene (COI) was amplified using universal primers LCO1490: $5^{\prime}$-GGT CAA CAA ATC ATA AAG ATA TTG G-3' (forward) and HC02198: 5'-TAA ACT TCA GGG TGA CCA AAA AAT CA-3' (reverse) [36]. Polymerase chain reactions (PCR) were performed in reaction volumes of $15 \mu \mathrm{l}$ containing the following reagents: $6.64 \mu \mathrm{l}$ of double-distilled water, $1.2 \mathrm{mM}$ of $\mathrm{MgCl}_{2}$ and $2 \mu \mathrm{l}$ of $10 \times$ PCR Buffer (Promega), $1 \mathrm{mM}$ of dNTPs (Sigma-Aldrich), $0.5 \mathrm{mM}$ of each primer, $1 \mu \mathrm{l}$ of BSA, $0.16 \mu \mathrm{l}$ of Super-Therm Taq polymerase (5 units $\mu \mathrm{l}^{-1}$; Separation Scientific, South Africa), and $2 \mu \mathrm{l}$ of DNA template. The following cycling profile was used: an initial denaturation step $\left(2 \mathrm{~min}\right.$ at $\left.94{ }^{\circ} \mathrm{C}\right), 40$ cycles of denaturation $\left(30 \mathrm{~s}\right.$ at $\left.94{ }^{\circ} \mathrm{C}\right)$, annealing ( $45 \mathrm{~s}$ at $\left.50{ }^{\circ} \mathrm{C}\right)$, extension $\left(1 \mathrm{~min}\right.$ at $\left.72{ }^{\circ} \mathrm{C}\right)$, and a final extension step $\left(10 \mathrm{~min}\right.$ at $\left.72{ }^{\circ} \mathrm{C}\right)$. Successful amplification was verified via gel electrophoresis on a $2 \%$ agarose gel. Sequencing was performed using a BigDye Terminator v3.1 Cycle Sequencing Kit, and reactions were run on an ABI 3730 DNA analyser (Applied Biosystems). Sequences were aligned and edited with the program MEGA v.6 [37], and a median joining haplotype network [38] was constructed using PopART [39].

\section{Results}

The final data set comprised 285 COI sequences, including 31 sequences of Hymenosoma projectum, 224 sequences of $H$. longicrure, and 30 sequences of $H$. orbiculare. From these sequences, 37 unique haplotypes were recovered. In the haplotype network (Fig. 2) sequences of $H$. longicrure, $H$. projectum, and $H$. orbiculare were recovered as three distinct clusters. Samples of $H$. projectum were found in the tropical and subtropical bioregions and on the Wild Coast, samples of H. longicrure were present in the subtropical region as well as along the Wild Coast, and samples of $H$. orbiculare were not found north of the warm-temperate bioregion (Fig. 3). Although the ranges of $H$. projectum and $H$. longicrure overlapped, each site had only a single species.

\section{Discussion}

This study re-investigated the distribution ranges of three species of crown crab along the eastern coastline of South Africa, with a specific focus on the subtropical marine bioregion and the understudied Wild Coast. It was found that $H$. projectum and $H$. longicrure are not strictly confined to specific portions of the coast, as previously believed [13, 26, 29, 32]. Hymenosoma longicrure is not a Wild Coast endemic but is also represented in the subtropical bioregion to the north.

The ranges of planktonic larval dispersers in southern Africa tend to be linked to the region's temperature-defined marine bioregions [8]. The finding that $H$. 


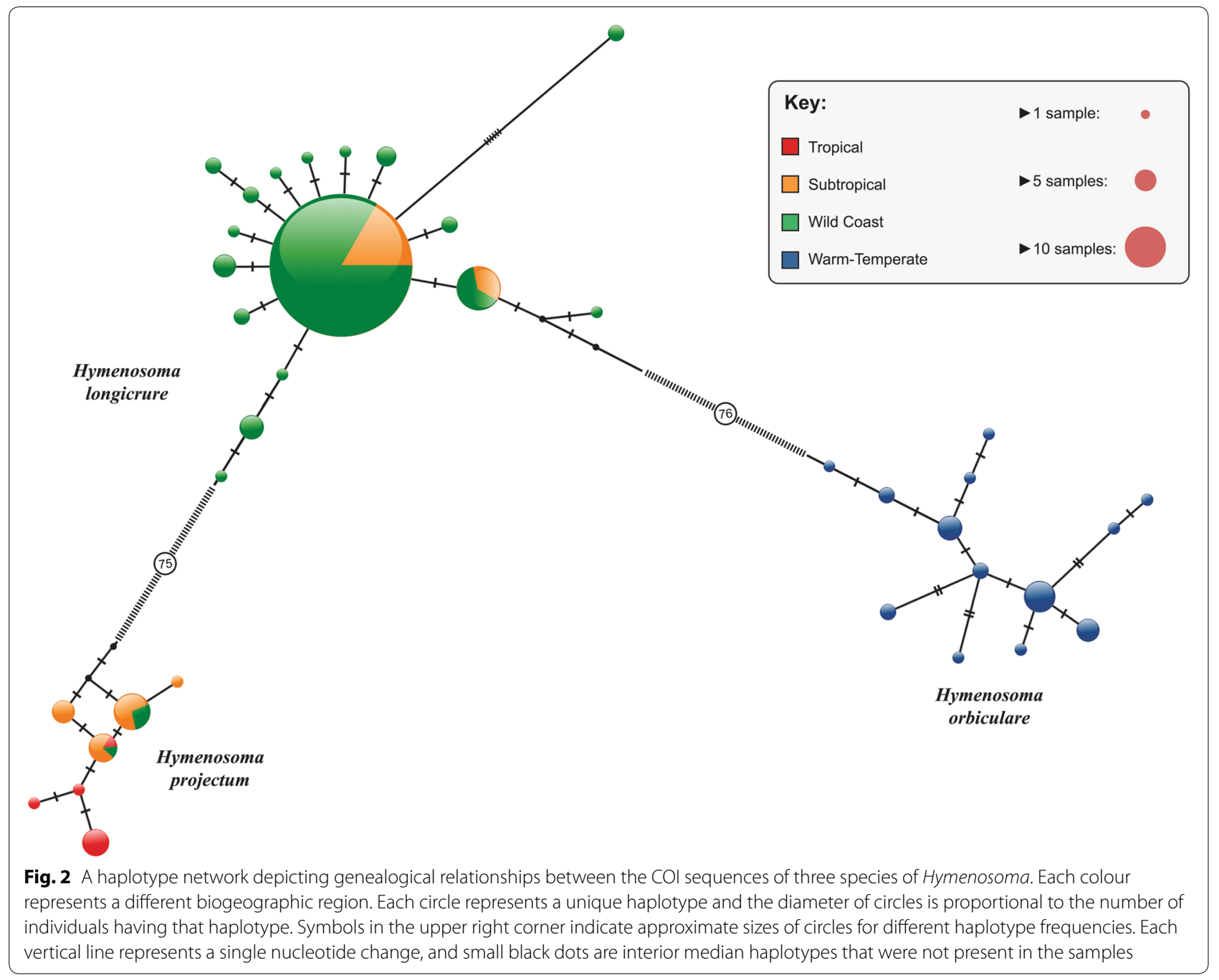

longicrure is not endemic to the Wild Coast can potentially be explained by the range of this species comprising the entire region considered to be subtropical by some authors [5, 23, 40,41], including the Wild Coast (but see [2]). Similarly, $H$. projectum could be primarily a tropical species that has established itself in some estuaries outside its normal range as a result of southward transport by the Agulhas Current. Occurrences of species south of their primary ranges have been reported for numerous other species along much of the east coast [33]. This would suggest that specimens from Mozambique identified as $H$. orbiculare [42, 43], and perhaps even from Zanzibar [44], were most likely specimens of H. projectum in their northern, tropical range.

With the exception of a genetic study of the limpets Scutellastra barbara and S. longicosta which, like previous studies on Hymenosoma longicrure, may have suffered from insufficient sampling to establish the complete ranges of its study species [24], there is presently no evidence for the premise that the Wild Coast transition zone could be a distinct marine bioregion, similar to its south-western counterpart. Like the majority of biogeographical studies, many genetic studies show that it is a region in which the ranges of regional sister lineages overlap $[8,45,46]$. However, unlike these other species, there is no evidence that the different species of Hymenosoma occur in the same estuaries. All estuaries previously sampled north of the Wild Coast were inhabited by $H$. projectum, which created the impression that $H$. longicrure is absent from the subtropical region. Lack of habitat sharing is most likely a consequence of abbreviated larval development [47] resulting in too few migrants arriving in an estuary at the same time to establish themselves, or too few to be detectable with moderate sampling effort. 


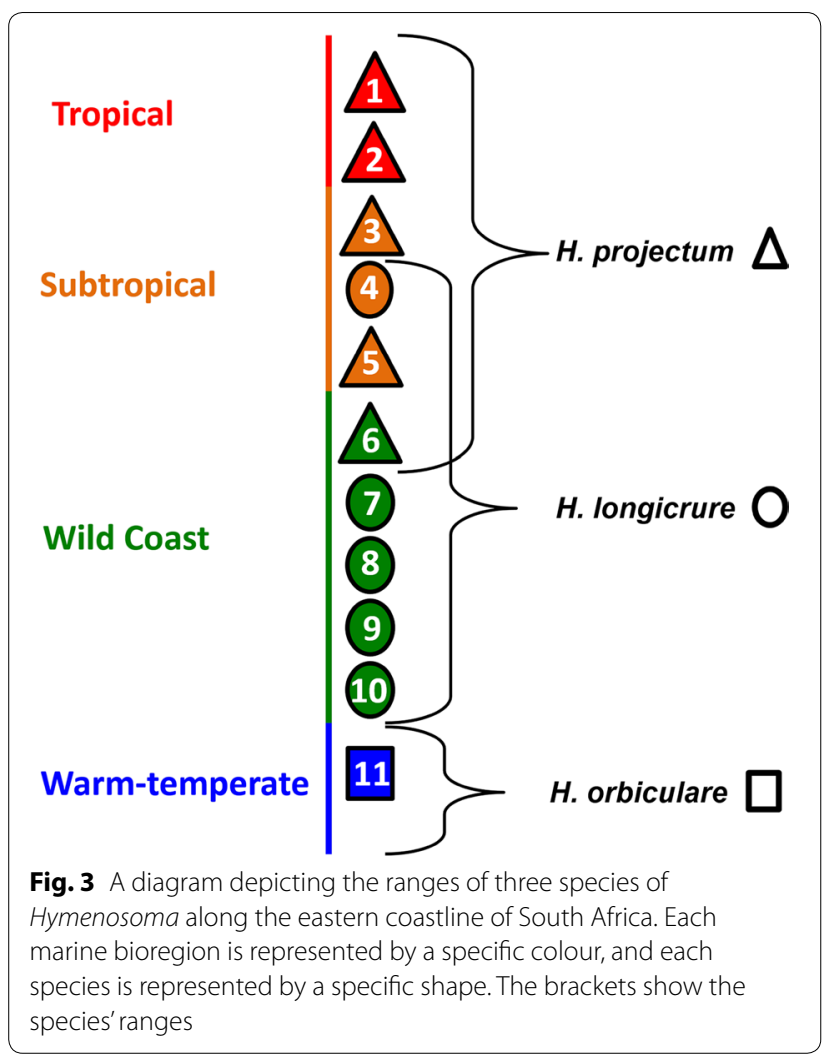

The identification of unique marine biogeographical regions that may harbour endemic species or populations is essential for the sustainable management of coastal resources. For example, when a widespread marine species is primarily exploited in one of the bioregions in which it occurs, there is a considerable risk of overexploiting a locally adapted population or cryptic species $[20,48]$. Because of this, networks of marine protected areas can only be effective if they encompass all of a region's marine biogeographic provinces $[3,20,49,50]$. The Wild Coast has two large marine protected areas in the north, Pondoland (near site 6) and Dwesa-Cwebe (near site 9), as well as some smaller reserves in the south [51]. These reserves play an important role in preserving the high biodiversity of this transitional zone, as they essentially protect faunal elements from several marine bioregions.

The fauna of the Wild Coast remains poorly studied, and virtually nothing is known about the biology of most of its estuaries. For example, a review of research conducted on South African estuaries [52] listed no biological or ecological information for $73 \%$ of the 84 estuaries between the Great Kei and the Mtamvuna Estuary south of Port Edward (Fig. 1). Comprehensive surveys aimed at documenting the region's fauna are urgently needed. This issue is particularly pressing because of the rapid increase in infrastructure developments in this region [53], including the construction of a coastal highway [54] that will make remote areas of the Wild Coast more accessible. This may facilitate the overexploitation of coastal resources, which is already a major problem along much of South Africa's coastline [55-60]. In addition, even though the present study rejected the idea that Hymenosoma longicrure is endemic to this region, it cannot be ruled out that the Wild Coast harbours endemic species. Several endangered or critically endangered species that occur in just a handful of estuaries have been recorded in the well-studied temperate coastal regions of South Africa [61-65], and it is possible that the Wild Coast also has species or genetically distinct populations with very small ranges that have not yet been documented.

\section{Authors' contributions}

PRT conceived the research and collected the samples. CMJ and JO generated the genetic data. CMJ, JO and AE-K analysed the data and prepared the figures. CMJ and PRT wrote the paper, with contributions from JO and AE-K. All authors read and approved the final manuscript.

\section{Acknowledgements}

We are grateful to Yolanda Qhaji, Isabelle Papadopoulos, Tiru Golla and Sophie Bader for their contributions.

\section{Competing interests}

The authors declare that they have no competing interests.

\section{Availability of data and materials}

The DNA sequences generated for this study have been submitted to the GenBank repository (accession numbers MH325652-MH325882).

\section{Consent for publication}

The authors declare that they consent to publish in this journal.

\section{Ethics approval and consent to participate}

Sampling was conducted under permit RES2016/70 issued by the Department of Agriculture, Forestry and Fisheries, Republic of South Africa.

\section{Funding}

This study was supported by the PADI Foundation (Grant No. 10981) and by an FRC/URC grant from the University of Johannesburg awarded to PRT. CM. and $\mathrm{JO}$ are grateful for bursary support from the University of Johannesburg and the NRF.

\section{Publisher's Note}

Springer Nature remains neutral with regard to jurisdictional claims in published maps and institutional affiliations.

Received: 14 February 2018 Accepted: 8 May 2018

Published online: 14 May 2018

\section{References}

1. Griffiths $C L$, Robinson TB, Lange L, Mead A. Marine biodiversity in South Africa: an evaluation of current states of knowledge. PLOS ONE. 2010;5:e12008.

2. Turpie J, Beckley L, Katua S. Biogeography and the selection of priority areas for conservation of South African coastal fishes. Biol Cons. 2000;92:59-72. 
3. Lombard AT, Strauss T, Harris J, Sink K, Attwood CHL. South African national spatial biodiversity assessment 2004: Technical report. Volume 4: Marine component. Pretoria: South African National Biodiversity Institute; 2004.

4. Costello MJ, Coll M, Danovaro R, Halpin P, Ojaveer H, Miloslavich P. A census of marine biodiversity knowledge, resources, and future challenges. PLOS ONE. 2010;5:e12110.

5. Emanuel BP, Bustamante RH, Branch GM, Eekhout S, Odendaal FJ. A zoogeographic and functional approach to the selection of marine reserves on the west coast of South Africa. S Afr J Mar Sci. 1992;12:341-54.

6. Bustamante $\mathrm{RH}$, Branch GM. Large scale patterns and trophic structure of Southern African rocky shores: the roles of geographic variation and wave exposure. J Biogeogr. 1996;23:339-51.

7. Whitfield AK. An estuary-association classification for the fishes of southern Africa. S Afr J Sci. 1994;90:411-7.

8. Teske PR, Papadopoulos I, Mmonwa KL, Matumba TG, McQuaid CD, Barke $N P$, et al. Climate-driven genetic divergence of limpets with different life histories across a southeast African marine biogeographic disjunction: different processes, same outcome. Mol Ecol. 2011;20:5025-41.

9. Bolton JJ, Leliaert F, De Clerck O, Anderson RJ, Stegenga H, Engledow HE, et al. Where is the western limit of the tropical Indian Ocean seaweed flora? an analysis of intertidal seaweed biogeography on the east coast of South Africa. Mar Biol. 2004;144:51-9.

10. Gopal K, Tolley KA, Groeneveld JC, Matthee CA. Mitochondrial DNA variation in spiny lobster Palinurus delagoae suggests genetically structured populations in the southwestern Indian Ocean. Mar Ecol Prog Ser. 2006:319:191-8

11. Ridgway T, Riginos C, Davis J, Hoegh-Guldberg O. Genetic connectivity patterns of Pocillopora verrucosa in Southern African marine protected areas. Mar Ecol Prog Ser. 2008;354:161-8.

12. Teske PR, Papadopoulos I, Zardi GI, McQuaid CD, Edkins MT, Griffiths CL, et al. Implications of life history for genetic structure and migration rates of southern African coastal invertebrates: planktonic, abbreviated and direct development. Mar Biol. 2007;152:697-711.

13. Teske PR, McLay CL, Sandoval-Castillo J, Papadopoulos I, Newman BK, Griffiths $C L$, et al. Tri-locus sequence data reject a "Gondwanan origin hypothesis" for the African/South Pacific crab genus Hymenosoma. Mol Phylogenet Evol. 2009;53:23-33.

14. Day JH. A guide to marine life on South African shores. Cape Town: A.A. Balkema; 1969.

15. Brown AC, Jarman N. Coastal marine habitats. In: Werger MJA, editor. Biogeography and ccology of southern Africa. Monographiae Biologicae. Dordrecht: Springer; 1978.

16. Branch G, Griffiths C, Branch M, Beckley L. Two oceans. A guide to the marine life of Southern Africa. Cape Town: David Philip; 1994.

17. Teske PR, McQuaid CD, Froneman PW, Barker NP. Impacts of marine biogeographic boundaries on phylogeographic patterns of three South African estuarine crustaceans. Mar Ecol Prog Ser. 2006;314:283-93.

18. Teske PR, Winker H, McQuaid CD, Barker NP. A tropical/subtropical marine biogeographic disjunction in southeastern Africa separates two evolutionarily significant units of an estuarine prawn. Mar Biol. 2009;165:1265-75.

19. von der Heyden S, Prochazka K, Bowie RCK. Significant population structure and asymmetric gene flow patterns amidst expanding populations of Clinus cottoides (Perciformes, Clinidae): application of molecular data to marine conservation planning in South Africa. Mol Ecol. 2008;17:4812-26.

20. von der Heyden S. Why do we need to integrate population genetics into South African marine protected area planning? Afr J Mar Sci. 2009:31:263-9.

21. Stephenson T, Stephenson A. Life between tidemarks on rocky shores. San Francisco: W.H. Freeman; 1972.

22. Wooldridge T, Dye AH, McLachlan A. The ecology of sandy beaches in Transkei. S Afr J Zool. 1981;16:210-8.

23. Harrison TD. Preliminary assessment of the biogeography of fishes in South African estuaries. Mar Freshw Res. 2002;53:479-90.

24. Mmonwa KL, Teske PR, McQuaid CD, Barker NP. Historical demography of southern African patellid limpets: congruence of population expansions, but not phylogeography. Afr J Mar Sci. 2015;37:11-20.

25. Wood LE, De Grave S, Daniels SR. Phylogeographic patterning among two codistributed shrimp species (Crustacea: Decapoda: Palaemonidae) reveals high levels of connectivity across biogeographic regions along the South African coast. PLOS ONE. 2017;12:e0173356.

26. Dawson J, Griffiths CL. Revision of the crown crabs, genus Hymenosoma (Crustacea: Hymenosomatidae), of South Africa. Afr Nat Hist. 2012;8:16-29.

27. Desmarest AJ. Considérations générales sur la classe des Crustacés, et descriptions des espèces de ces animaux, qui vivent dans la mer, sur les côtes, ou dans les eaux douces de la France: i-xix, 1-446, IV, pls. 1-56. (Paris, Strasbourg). 1825;446.

28. Stimpson W. Prodromus descriptionis animalium evertebratorum, quae in Expeditione ad Oceanum Pacificum Septentrionalem, e Republica Federata missa, Cadwaladaro Ringgold et Johanne Rodgers ducibus, observavit et descripsit. V. Crustacea Ocypodoidea. Proc Acad Natl Sci Phila. 1857;10:93-110

29. Edkins MT, Teske PR, Papadopoulos I, Griffiths CL. Morphological and genetic data suggest that southern African crown crabs, Hymenosoma orbiculare, represent five distinct species. Crustaceana. 2007;80:667-83.

30. Teske P, Papadopoulos I, Barker N, Mcquaid C, Beheregaray L. Mitonuclear discordance in genetic structure across the Atlantic/Indian Ocean biogeographical transition zone. J Biogeogr. 2014;41:392-401.

31. Peer N, Perissinotto R, Taylor RH, Miranda NAF. Temporal variations in the diversity of true crabs (Crustacea: Brachyura) in the St Lucia Estuary, South Africa. Afr Invert. 2014;55:39-65.

32. Qhaji Y, Jansen van Vuuren B, Papadopoulos I, McQuaid CD, Teske PR. A comparison of genetic structure in two low-dispersal crabs from the Wild Coast, South Africa. Afr J Mar Sci. 2015;37:345-51.

33. Beckley LE. Dispersal of coral reef fish larvae by the Agulhas Current, South Africa. In: 76th annual meeting the American Society of Ichthyologists and Herpetologists;1996.

34. Van der Elst R. Shelf ichthyofauna of Natal. In: Schumann EH, editor. Coastal Ocean studies off Natal, South Africa. Lecture notes on coastal and estuarine studies, vol. 26. New York: Springer; 1988. p. 209-25.

35. Doyle JJ, Doyle JL. A rapid DNA isolation procedure for small quantities of fresh leaf tissue. Phytochem Bull. 1987;19:11-5.

36. Folmer $\mathrm{O}$, Black M, Hoeh W, Lutz R, Vrijenhoek R. DNA primers for amplification of mitochondrial cytochrome c oxidase subunit I from diverse metazoan invertebrates. Mol Mar Biol Biotechnol. 1994;3:294-9.

37. Tamura K, Stecher G, Peterson D, Filipski A, Kumar S. MEGA6: molecular evolutionary genetics analysis version 6.0. Mol Biol Evol. 2013;30:2725-9.

38. Bandelt HJ, Forster P, Röhl A. Median-joining networks for inferring intraspecific phylogenies. Mol Biol Evol. 1999;16:37-48.

39. Leigh JW, Bryant D. Popart: full-feature software for haplotype network construction. Methods Ecol Evol. 2015;6:1110-6.

40. Day JH. Estuarine ecology: with particular reference to Southern Africa. Cape Town: A.A. Balkema; 1981.

41. Day JH, Blaber S, Wallace J. Estuarine fishes. Estuarine ecology with particular reference to southern Africa. Cape Town: A.A. Balkema; 1981. p. 197-221.

42. Macnae W, Kalk M. A natural history of Inhaca Island, Moçambique. Johannesburg: Witwatersrand University Press; 1958.

43. Dornelas M, Paula J, Macia A. The larval development of Hymenosoma orbiculare Desmarest, 1825 (Crustacea: Decapoda: Brachyura: Hymenosomatidae). J Nat Hist Lond. 2003;37:2579-97.

44. Barnard KH. Descriptive catalogue of South African Decapod Crustacea. Ann S Afr Mus. 1950;38:1-837.

45. Teske PR, Papadopoulos I, Newman BK, Dworschak PC, McQuaid CD, Barker NP. Oceanic dispersal barriers, adaptation and larval retention: an interdisciplinary assessment of potential factors maintaining a phylogeographic break between sister lineages of an African prawn. BMC Evol Biol. 2008:8:341.

46. Zardi Gl, McQuaid CD, Teske PR, Barker NP. Unexpected genetic structure of mussel populations in South Africa: indigenous Perna perna and invasive Mytilus galloprovincialis. Mar Ecol Prog Ser. 2007;337:135-44.

47. Papadopoulos I, Newman BK, Schoeman DS, Wooldridge TH. Influence of salinity and temperature on the larval development of the crown crab, Hymenosoma orbiculare (Crustacea: Brachyura: Hymenosomatidae). Afr J Aquat Sci. 2006;31:43-52.

48. Teske P, Forget F, Cowley P, Von Der Heyden S, Beheregaray LB. Connectivity between marine reserves and exploited areas in the philopatric reef fish Chrysoblephus laticeps (Teleostei: Sparidae). Mar Biol. 2010;157:2029-42. 
49. Boersma PD, Parrish JK. Limiting abuse: marine protected areas, a limited solution. Ecol Econ. 1999;31:287-304.

50. Hamilton SL, Caselle JE, Malone DP, Carr MH. Incorporating biogeography into evaluations of the Channel Islands marine reserve network. Proc Natl Acad Sci. 2010;107:18272-7.

51. Tunley K. State of management of South Africa's marine protected areas WWF South Africa Report Series; 2009.

52. Whitfield AK, Baliwe NG. A century of science in South African estuaries: bibliography and review of research trends. SANCOR occasional report no 7. 2013;289.

53. Tessaro D, Kepe T.'Development' at the crossroads: biodiversity and landuse tensions on South Africa's Wild Coast. Int J Sustain Dev World Ecol. 2014;21:471-9.

54. Giampiccoli A, Saymaan M. Community-based tourism, responsible tourism, and infrastructure development and poverty. Afr J Hosp Tour Leisure. 2017:6:1-28.

55. Attwood CG, Mann BQ, Beaumont J, Harris JM. Review of the state of marine protected areas in South Africa. S Afr J Mar Sci. 1997;18:341-67.

56. Calvo-Ugarteburu G, Raemaekers S, Halling C. Rehabilitating mussel beds in Coffee Bay, South Africa: towards fostering cooperative small-scale fisheries governance and enabling community upliftment. Ambio. 2017:46:214-26.

57. Fielding PJ, Weerts KA, Forbes AT. Macroinvertebrate communities associated with intertidal and subtidal beds of Pyura stolonifera (Heller) (Tunicata: Ascidiacea) on the Natal coast. S Afr J Zool. 1994;29:46-53.
58. Kyle R, Pearson B, Fielding PJ, Robertson WD, Birnie SL. Subsistence shellfish harvesting in the Maputaland Marine Reserve in northern KwaZuluNatal, South Africa: rocky shore organisms. Biol Conserv. 1997;82:183-92.

59. Fulton EA, Smith AD, Smith DC, van Putten IE. Human behaviour: the key source of uncertainty in fisheries management. Fish Fish. 2011;12:2-17.

60. Raemaekers S, Hauck M, Bürgener M, Mackenzie A, Maharaj G, Plagányi $E$ E, et al. Review of the causes of the rise of the illegal South African abalone fishery and consequent closure of the rights-based fishery. Ocean Coast Manag. 2011;54:433-45.

61. Allanson BR. On the systematics and distribution of the molluscan genus Siphonaria in South Africa. Hydrobiologia. 1958;12:149-80.

62. Allanson BR, Herbert D. A newly discovered population of the critically endangered false limpet Siphonaria compressa Allanson, 1958 (Pulmonata: Siphonariidae), with observations on its reproductive biology. S Afr J Sci. 2005;101:95-7.

63. Penrith MJ. Redescription of Pandaka silvana (Barnard) (Pisces: Gobiidae). Ann S Afr Mus. 1972;60:105-8

64. Whitfield AK. Threatened fishes of the world: hippocampus capensis Boulenger, 1900 (Syngnathidae). Environ Biol Fishes. 1995;44:362.

65. Whitfield AK. Threatened fishes of the world: Syngnathus watermeyer Smith, 1963 (Syngnathidae). Environ Biol Fishes. 1995;43:1-2.
Ready to submit your research? Choose BMC and benefit from:

- fast, convenient online submission

- thorough peer review by experienced researchers in your field

- rapid publication on acceptance

- support for research data, including large and complex data types

- gold Open Access which fosters wider collaboration and increased citations

- maximum visibility for your research: over 100M website views per year

At BMC, research is always in progress.

Learn more biomedcentral.com/submissions 